\title{
ОСОБЕННОСТИ ПРОЦЕДУРЫ ВЫКУПА СОБСТВЕННЫХ АКЦИЙ ЭМИТЕНТОМ ДЛЯ ИНВЕСТОРА
}

\author{
(c) 2020 Левченко Лариса Владимировна \\ кандидат экономических наук, доцент \\ Самарский государственный экономический университет, Россия, Самара \\ (c) 2020 Осина Дарья Сергеевна \\ магистрант, 2 курс \\ Самарский государственный экономический университет, Россия, Самара
}

В статье рассматривается характер, набирающей в последнее время популярность среди менеджмента компаний, сделки обратного выкупа акций (buy-back). Указаны положительные и отрицательные черты данного механизма увеличения доли в уставном капитале. На конкретных примерах отечественных контрагентов проводится анализ процедуры buy-back.

Ключевые слова: акции, дивиденд, инвестиционный фонд, облигации, эмитент.

За последние годы российский рынок акций претерпел заметные изменения. Так, наблюдаются положительные тенденции роста капитализации фондового рынка РФ, повышения рейтингов ведущих российских компаний, появления новых финансовых игроков [1]. При этом в отечественной практике среди менеджмента компаний набирает популярность механизм увеличения доли собственных акций в уставном капитале компаний, что имеет как положительные, так и отрицательные черты.

Выкуп акций на заемные деньги представляют особый риск для инвестора. Риск состоит в том, что компания может получить не тот эффект, который ожидается от операции buy-back, по причине наличия у юридического лица необслуживаемых обязательств. Стоит отметить, что существует практика незадолго до объявления выкупа на рынке появления облигаций, размещенных эмитентом. Таким образом, от дефолта, который может произойти, могут пострадать и держатели облигаций, помимо акционеров. Такой исход вероятен для эмитентов из второго и третьего эшелонов, нежели для крупных высоколиквидных компаний [10].

Провал котировок акций является самым актуальным временем для проведения программы «buy-back» [3]. Выкупая собственные акции в это время, эмитент преследует несколько основных целей, например, таких как: поддержка капитализации или же приобретение активов по минимальной цене, для того, чтобы в будущем вернуть их на рынок после их существенно удорожания. Стоит отметить, что в последнее время проведение операции buy-back происходит на ценовых пиках, нежели на обвале рынка. В структуре покупок акций возрастает доля корпораций и падает доля инвестиционных фондов и доли домохозяйств [4].

На российском фондовом рынке процедуры по выкупу своих акций проходят более благополучно, так как не происходят на «перегретом» рынке, не опираются на ликвидность, которая не представляет ценности, и не пользуются огромным спросом. Но стоит отметить, что объемы рынка несопоставимы, а сами сделки носят единичный характер и имеют меньший процент успешности [5]. Одним из самых ярких и удачливых примеров операции buy-back в России можно назвать нефтяную компанию ПАО «Лукойл» (см. таблицу 1). Но на этом компания не останавливается, в ближайшие пару лет компания планирует выкупить собственные акции на сумму более 235 миллиардов рублей. Нельзя не отметить, что одним из положительных признаком компании является то, менеджмент ПАО «Лукойл» сам активно скупает акции на рынке [9].

Несмотря на то, что многие компании, воспользовавшиеся операцией buy-back, имели положительный результат, существуют компании, которым эта операция не помогла долгосрочно поднять котировки [8]. К таким компаниям можно отнести: Лента, потеряли почти 17\%; ТМК, около 33\%; серия выкупа собственных акций Норникеля, часть из которых завершилась негативно или же нейтрально для инвесторов; Магнит, акции которого, после выкупа на 22 миллиарда рублей, остались с нулевой динамикой [6]. 
Таблица 1. Статистика приобретений собственных акций компанией ПАО «Лукойл» (в т.ч. ГДР)

\begin{tabular}{|c|c|c|c|c|}
\hline \multicolumn{5}{|c|}{ Программа от 30.08.2018 г. Завершена 20.08.2019 г. } \\
\hline ГОД & МЕСЯЦ & ОБЪЕМ, ШТ. & $\begin{array}{c}\text { Средняя цена, } \\
\text { долл. США }\end{array}$ & $\begin{array}{c}\text { Объем, } \\
\text { млн. долл. США }\end{array}$ \\
\hline \multirow{4}{*}{2018} & Сентябрь & 1480816 & 70,27 & 104,1 \\
\hline & Октябрь & 2671706 & 73,95 & 197,6 \\
\hline & Ноябрь & 2388204 & 73,36 & 175,2 \\
\hline & Декабрь & 6186975 & 75,14 & 464,9 \\
\hline \multirow{7}{*}{2019} & Январь & 1831809 & 76,66 & 140,4 \\
\hline & Февраль & 5575633 & 82,60 & 460,6 \\
\hline & Март & 6013964 & 87,43 & 525,8 \\
\hline & Апрель & 4641380 & 88,24 & 409,5 \\
\hline & Май & 3551807 & 81,84 & 290,7 \\
\hline & Июнь & 2269744 & 80,81 & 183,4 \\
\hline & Август & 591418 & 80,83 & 47,8 \\
\hline ИТОГО & & 37203456 & & 3000,0 \\
\hline
\end{tabular}

Одним из нашумевших выкупов, который закончился провалом, была сделка между ПАО НК «Роснефть» и ОАО «ТНК-ВР Холдинг». На тот момент времени ОАО «ТНК-ВР Холдинг» занимала третье место в России по объёму добычи нефти и на протяжении долгого времени выплачивала высокие дивиденды. Управление компанией было сосредоточено на совместном управлении российской и британской компаний, тем самым повышалась привлекательность для потенциальных инвесторов [2]. На фоне произошедшего конфликта между акционерами компаний в 2008 году, ПАО НК «Роснефть», решила выкупить акции компании, так как была заинтересована в единоличном управлении. На собрании акционеров количество необходимых голосов было собрано. Первоначальным решением была заморозка дивидендов, точные сроки не устанавливались. Таким образом, акции теряли свою инвестиционную привлекательность, тем самым подталкивая инвесторов избавляться от них (стоимость за одну акцию снизилась до 25 рублей, с изначальной стоимости 90 рублей) [7]. ПАО НК «Роснефть» начинает программу по обратному выкупу акций и выкупает акции нефтедобывающей компании с дисконтом в 70\%. Так, уже являясь собственником ПАО НК «Роснефть», выплатила сама себе дивиденды ОАО «ТНК-ВР Холдинг», далее выводит бумаги из обращения на бирже. Подводя выводы по данной сделке, укажем, что выгоды от данной операции buyback акционеры не извлекли, а только наоборот, понесли огромные убытки.

\section{Библиографический список}

1. Левченко Л.В., Коновалова М. Е., Кузьмина О. Ю. Современное состояние и тенденции развития российского рынка акций // Вопросы экономики и права. - 2017. № 113. - С.13-16.

2. Никулина О.В. Транснационализация банковского бизнеса как форма экспансии коммерческих банков в условиях глобализации мировой экономики. Economics: Yesterday, Today and Tomorrow. 2017, Vol. 7, Is. 4A.C. $230-238$.

3. Радюкова Я. Ю., Федорова А.Ю., Толстых Т. Н. [и др.] Развитие финансовой системы в условиях модернизации экономики России: кол. монография. Тамбов: Изд-во ТРОО «Бизнес-Наука-Общество», 2014.

4. Сорокин Д.Е. Российская экономика: развитие и ограничители // Россия и современный мир. - 2015. № 2 (79). С. 48-68.

5. Филиппов Д.И. О влиянии финансовых технологий на развитие финансового рынка // Российское предпринимательство. Т.19. № 5. 2018. С. 1437-1463.

6. Центральный банк РФ. Основные направления развития финансового рынка РФ на период 2018-2020 годов. Москва, 2019.- С. 22-23. [Электронный ресурс]: - Режим доступа: https://www.cbr.ru/Content/Document/ File/71220/main_directions.pdf

7. Шестакова Е. Чего стоит ожидать российскому бизнесу? Прогноз экономических перемен на 2019 год // Финансовая газета, № 32. 2018. [Электронный ресурс]. - https:// fingazeta.ru, заголовок с экрана. 
8. Левченко Л.В. Венчурный капитал и источники его привлечения // Вестник Самарског государственного экономического университета.-2012. № 11(97).- С.74-75.

9. Рязанова О.Е. Институт промышленной собственности в инновационной экономике. М.,2014.- C.43-44.

10. Абрамов Д. В., Петров Н. А., Михайлов А. М. Современное состояние институциональной среды региона, как фактор, влияющий на отток иностранных инвестиций // Вестник Российского университета дружбы народов. Серия: Экономика. 2018. Т. 26. № 2. С. 283-295 